\title{
PENYULUHAN PENGGUNAAN MASKER DAN CUCI TANGAN BAGI PEDAGANG DI PASAR LEGI SURAKARTA
}

\section{COUNSELING ON THE USE OF MASKS AND HAND WASHING FOR MERCHANTS IN LEGI SURAKARTA MARKET}

\author{
Wahyu Tri Hastiningsih ${ }^{\left.1^{*}\right)}$, A Anditha Sari ${ }^{2)}$ \\ 1,2Politeknik Indonusa Surakarta \\ ${ }^{1}$ Email: wahyutri@ poltekindonusa.ac.id
}

\begin{abstract}
Abstrak: Merebaknya Covid 19 yang sudah menjadi pandemik di Indonesia dan dunia, menjadikan masyarakat untuk berperilaku bersih dan sehat. Perilaku tersebut dengan cara untuk selalu menggunakan masker dan sering mencuci tangan. Tujuan pengabdian masyarakat ini adalah memberikan pengarahan dan penyuluhan penggunaan masker dan cara mencuci tangan yang baik dan benar. Pelaksanaan pengabdian masyarakat dilakukan di sekitar pasar sementara Pasar Legi Surakarta dengan cara membagikan secara langsung kepada para pedagang berupa masker dan pemberian nasi bungkus, teknik mencuci tangan dan penyerahkan pula ember beserta kelengkapannya. Dari pelaksanaan pengabdian masyarakat ini telah memberikan secara nyata masker yang langsung digunakan oleh para pedagang, makanan yang dikonsumsi serta tempat cuci tangan pagi pedagang diseputaran Pasar Legi Surakarta.
\end{abstract}

Kata Kunci: Covid 19, Pengabdian Masyarakat, Pasar Legi

Abstract: The spread of COVID 19 has become a pandemic in Indonesia and the world, making the community to behave clean and healthy. The behavior is in a way to always use masks and wash hands often. The purpose of this community service is to provide guidance and counseling on the use of masks and good and correct hand washing. The implementation of public service is done around the market while the Legi Surakarta market by sharing directly with the traders in the form of masks and feeding rice wrap, hand washing techniques, and also the bucket and the completeness of the accessories. From the implementation of this community service has given a real mask directly used by the traders, food consumed and the washing place of the morning trader was in the market Legi Surakarta.

Keywords: Covid 19, community service, Pasar Legi

\section{PENDAHULUAN}

Desember 2019 merupakan awal terjadi munculnya sebuah virus yang dinamakan COVID 19. Yang awal terjadi di Wuhan, China, COVID-19 telah disebut pandemi oleh World Health Organization (WHO) (Lau et al., 2020). Data Worldometers pada Minggu (19/4/2020) pagi, jumlah kasus Covid-19 secara global mencapai 2.324.731 kasus (Bramasta, 2020). Untuk Di Indonesia terjadi 
INTEGRITAS : Jurnal Pengabdian

Vol 4, No 1, Juli 2020

ISSN $2580-7978$ (cetak) ISSN $2615-0794$ (online)

penambahan kasus konfirmasi positif (virus corona Covid-19) sebanyak 327. Total akumulasi kasus positif 6.575 bahkan untuk di Jawa Tengah menjadi 349 yang positif corona, sembuh 51dan meninggal 44 (Rozie, 2020).

Penyakit coronavirus (COVID-19) disebabkan oleh SARS-COV2 dan menjadikan penyebab dari penyakit fatal yang telah menjadi perhatian besar kesehatan masyarakat global (Rothan \& Byrareddy, 2020). Dengan menyebarnya Covid 19 hampir diseluruh belahan bumi ini, berdampak pada banyaknya masayarakat terutama di Indonesia. Masyarakat diwajibkan bekerja dirumah, belajar dirumah dan beribadah dirumah. Hal ini merupakan anjuran pemerintah. Namun dipasar sementara Pasar Legi Surakarta. yang merupakan salah satu pasar induk terbesar di Kota Surakarta dengan jam buka dimulai pukul 08.00 hingga 16.00, tetap ramai dipenuhi oleh para pedagang dan pembeli yang bertransaksi aneka bahan pokok. Dengan adanya transaksi jual beli dengan uang tunai, menjadikan para pedagang selalu memegang uang tunai. Tidak hanya dari dengan memegang uang secara tunai saja, seringnya menggunakan tangan sebagai media didalam mengambil bahan dan barang sebagai wujud transaksi sehingga menjadikan tangan kotor. Kotoran yang menempel pada tangan ini lah yang dapat menjadikan media penularan berbagai penyakit terutama virus Covid 19. Dengan adanya hal demikian, perlu adanya sebuah kesadaran untuk dapat menjaga pola hidup bersih terutama dalam mencuci tangan dan penggunaan masker setiap saat.

\section{METODE PELAKSANAAN}

Pelaksanaan kegiatan pengabdian masyarakat ini dilakukan dengan tiga hal (1) pembagian masker dan perlengkapan cuci tangan penyuluhan mencuci tangan kepada para pedagang dan warga sekitar (2) dan (3) bagi nasi bungkus untuk berbuka puasa. Target sasaran kegiatan pengabdian masyarakat ini adalah (1) pedagang dan (2) pembeli di sekitar. 
INTEGRITAS : Jurnal Pengabdian

Vol 4, No 1, Juli 2020

ISSN $2580-7978$ (cetak) ISSN 2615 - 0794 (online)

\section{HASIL DAN PEMBAHASAN}

Pasar menjadi salah satu tempat yang rawan dalam penyebaran virus COVID-19. Hal ini dikarenakan pasar sebagai tempat terjadinya jual beli kebutuhan pokok masyarakat. Proses interaksi dan transaksi yang terjadi di dalam pasar memudahkan transmisi penyebaran COVID-19. Melihat hal ini, perlu adanya regulasi dan pola hidup yang diterapkan kepada pedagang dan pembeli yang ada di pasar.

Sebagai bentuk regulasi, akhirnya pemerintah kota surakarta telah membuat aturan di pasar bagi masyarakat yang akan masuk pasar diwajibkan menggunakan masker dan cuci tangan yang tersedia di pintu masuk pasar. Namun hal ini kurang diterapkan di pasar sementara Pasar Legi Surakarta. Hal ini terjadi, karena sifat pasar yang sementara dan letak tempat berjualan para pedagang yang tersebar membuat protokol kesehatan berjalan kurang maksimal. Terlihat pedagang, pembeli, maupun tukang parkir yang datang ke pasar belum semuanya menggunakan masker. Sarana cuci tangan pun, hanya ada di dua titik yang letaknya kurang bisa menjangkau seluruh pedagang maupun pembeli.

Melihat hal ini, kami melaksanakan kegiatan penyuluhan tentang mencuci tangan yang baik dan benar. Kegiatan ini dilakukan dengan sasaran penjual dan pembeli di pasar sementara Pasar Legi. Kami mengajak beberapa pedagang dan pembeli yang ada di sekitar pasar. Kami melakukan penyuluhan dengan berbincang langsung ke beberapa pedagang serta pembeli dan meminta untuk melakukan simulasi dengan menggunakan perlengkapan yang telah disediakan.

Dari hasil simulasi tersebut ditemukan bahwa mereka belum menerapkan cuci tangan yang benar. Melalui perbincangan face to face memudahkan kami untuk mengedukasi cuci tangan dengan lebih baik. Setelahnya, kami membagikan masker atas bentuk partisipasi pedagang dan pembeli serta meletakkan perlengkapan cuci tangan ke beberapa titik yang belum terjangkau. Harapannya setelah diberikannya ember serta kelengkapannya, para pedagang dan pembeli dapat melakukan pencucian tangan dengan mudah dan setiap saat. 


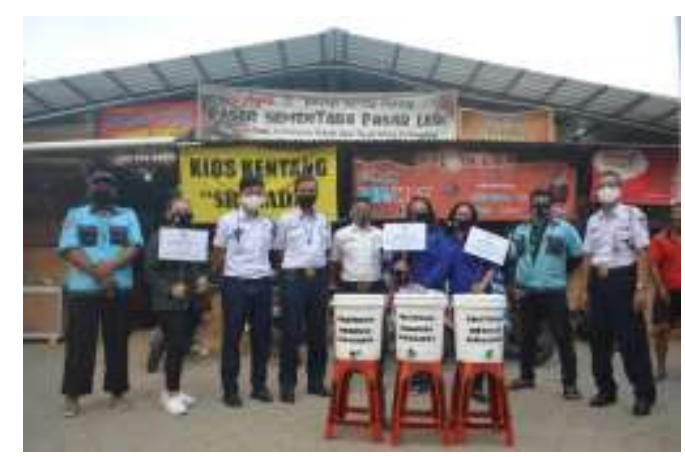

Gambar 1. Penyerahan simbolis

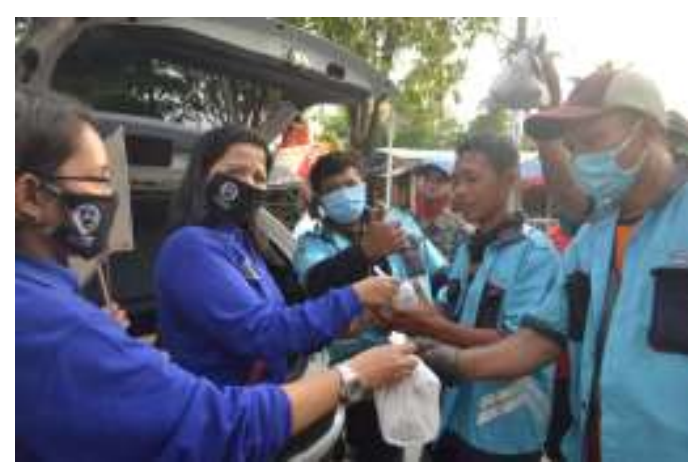

Gambar 2. Pemberian nasi bungkus

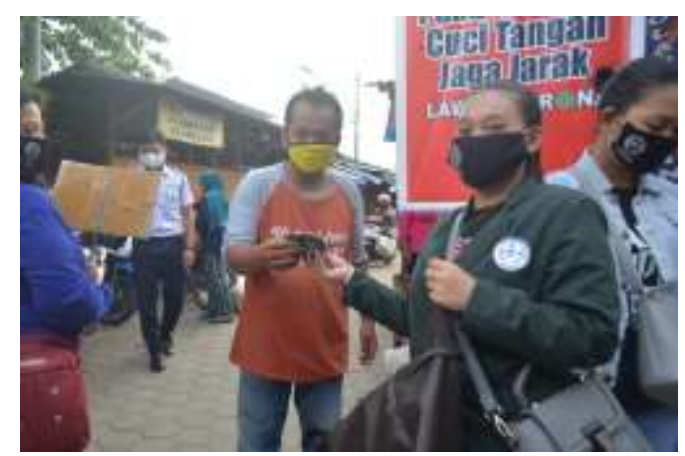

Gambar 3. Penyerahan masker oleh mahasiswa

\section{KESIMPULAN}

Dalam pelaksanan pengabdian ini dapat disimpulkan bahwa dengan dilaksanakannya penyuluhan pencucian tangan dan penggunaan masker telah memberikan dampak yang baik dalam menerapkan hidup sehat dan mengurangi dampak penyebaran COVID 19. Pemberian ember serta kelengkapannya telah digunakan oleh pedagang dan warga sekitar untuk setiap saat mencuci tangan. Dengan adanya kegiatan ini diharapkan dapat terus diterapkan oleh pedagang dan masyarakat sekitar serta tetap menjaga keberlangsungan ember tersebut untuk tetap digunakan sesuai dengan kegunaannya. 
INTEGRITAS : Jurnal Pengabdian

Vol 4, No 1, Juli 2020

ISSN 2580-7978 (cetak) ISSN 2615-0794 (online)

\section{UCAPAN TERIMA KASIH}

Pada kesempatan ini, diucapkan terima kasih kepada Ir. Suci Purwandari, MM selaku Direktur Politeknik Indonusa, Henny Kustini S.ST., MM selaku Kepala Program Studi D3 Perhotelan, Kepala Unit Penelitian, Lembaga Penelitian dan Pengabdian kepada Masyarakat beserta staffnya yang telah memberikan banyak dukungan teknis, fasilitas, dan administrasi guna kelancaran pengabdian. Serta masyarakat sekitar (pedagang, tukang becak dan lainnya) pasar sementara Pasar Legi Surakarta

\section{DAFTAR PUSTAKA}

Bramasta, D. B. (2020). Update Covid-19 di Dunia 19 April: 2,3 Juta Kasus, 595.467 Sembuh, 160.434 Meninggal. Retrieved April 18, 2020, from www.kompas.com website: https://www.kompas.com/tren/read/2020/04/19/071600465/update-covid-19di-dunia-19-april--2-3-juta-kasus-595.467-sembuh-160.434?page=all

Dey, B. L., Yen, D., \& Samuel, L. (2020). Digital consumer culture and digital acculturation. International Journal of Information Management, 51(July), 102057. https://doi.org/10.1016/j.ijinfomgt.2019.102057

Eigenraam, A. W., Eelen, J., van Lin, A., \& Verlegh, P. W. J. (2018). A Consumer-based Taxonomy of Digital Customer Engagement Practices. Journal of Interactive Marketing, 44, 102-121. https://doi.org/10.1016/j.intmar.2018.07.002

Idhom, A. M. (2020). Update Corona Indonesia 21 April 2020 \& Data Covid-19 Dunia Terkini. Retrieved April 22, 2020, from tirto.id website: https://tirto.id/update-corona-indonesia-21-april-2020-data-covid-19-duniaterkini-ePYZ 